European Welfare Policy 


\section{Also by Vic George}

Modern Thinkers on Welfare (edited with R. Page)

Welfare and Ideology (with P. Wilding)

Social Policy Towards 2000 (edited with S. Miller)

Poverty Amidst Affluence: Britain and the United States (with I. Howards)

Wealth, Poverty and Starvation

The Impact of Social Policy (with P. Wilding)

Socialism, Social Welfare and the Soviet Union (with N. Manning)

Poverty and Inequality in Common Market Countries (edited with R. Lawson)

Ideology and Social Welfare (with P. Wilding)

Social Security and Society

Motherless Families (with P. Wilding)

Foster Care: Theory and Practice

Social Security: Beveridge and After

\section{Also by Peter Taylor-Gooby}

Markets and Managers (edited with Robyn Lawson)

Dependency Culture (with H. Lean)

Social Change, Social Welfare and Social Science

The Private Provision of Public Welfare (with Elim Papadakis)

Public Opinion, Ideology and the Welfare State

Social Theory and Social Welfare (with J. Dale)

Political Philosophy and Social Welfare (with R. Plant and H. Lesser) 


\section{European Welfare Policy}

Squaring the Welfare Circle

Edited by

Vic George

and

Peter Taylor-Gooby

Macmillan Education 
EUROPEAN WELFARE POLICY

Selection, editorial matter and Introduction (C) Vic George and Peter Taylor-Gooby 1996

Individual chapters (in order) @ Vic George; Roger Lawson;

Linda Hantrais; Arthur Gould; Peter Taylor-Gooby; Mauro

Niero; Peter Stathopoulos; Elisabet Almeda and Sebastia

Sarasa; Vic George; Peter Taylor-Gooby 1996

Softcover reprint of the hardcover 1st edition 1996 978-0-333-60916-3

All rights reserved. No part of this book may be used or reproduced in any manner whatsoever without written permission except in the case of brief quotations embodied in critical articles or reviews.

For information, address:

St. Martin's Press, Scholarly and Reference Division, 175 Fifth Avenue, New York, N.Y. 10010

First published in the United States of America in 1996

ISBN 978-0-333-60917-0 ISBN 978-1-349-24630-4 (eBook)

DOI 10.1007/978-1-349-24630-4

Library of Congress Cataloging-in-Publication Data

European welfare policy : squaring the welfare circle / edited by Vic

George and Peter Taylor-Gooby.

p. $\mathrm{cm}$.

Includes bibliographical references and index.

ISBN 978-0-312-15795-1(cloth)

1. European Union countries-Social policy. 2. Public welfare-

-European Union countries. I. George, Victor. II. Taylor-Gooby, Peter.

HN377.E93 1996

$361.6^{\prime} 1^{\prime} 094-\mathrm{dc} 20$

95-42138

CIP 


\section{Contents}

Acknowledgements vi

List of Tables vii

List of Contributors viii

Introduction ix

1 The Future of the Welfare State

Vic George 1

2 Germany: Maintaining the Middle Way

Roger Lawson 31

3 France: Squaring the Welfare Triangle

Linda Hantrais 51

4 Sweden: The Last Bastion of Social Democracy

Arthur Gould

5 The United Kingdom: Radical Departures and Political Consensus

Peter Taylor-Gooby

6 Italy: Right Turn for the Welfare State?

Mauro Niero

7 Greece: What Future the Welfare State?

Peter Stathopoulos

8 Spain: Growth to Diversity

Elisabet Almeda and Sebastia Sarasa

9 The Demand for Welfare

Vic George

10 The Response of Government: Fragile Convergence?

Peter Taylor-Gooby

Index 


\section{Acknowledgements}

The authors and publishers wish to thank the following for permission to use copyright material: The Controller of HMSO for Tables 1.9, 9.3 from Social Trends 1994 and Table 5.2 from 'Households Below Average Income', DSO; International Social Security Association for Table 1.7 from Whiteford and Bradshaw, 'Benefits and Incentives for Lone Parents: A Comparative Analysis', International Social Security Review, 47, 3-4/94, table 1, p. 71; Office for Official Publications of the European Communities for Tables 9.2, 9.3, 9.4 for data produced by Eurostat from the Labour Force Survey (as reprinted in Employment in Europe, 1994, A Social Portrait of Europe, 1991 and Poverty Statistics in the Late 1980s); Organisation for Economic Co-operation and Development for Tables 1.1, 1.2, 1.3, 1.4, 1.5, 1.6, 1.8, 1.10, 9.1, 10.1 for data from OECD sources and OECD Economic Studies, No. 17, 1991, and Economic Outlook, No. 55, 1994. Copyright (C) OECD. Every effort has been made to trace all the copyright-holders, but if any have been inadvertently overlooked the publishers will be pleased to make the necessary arrangement at the first opportunity. 


\section{List of Tables}

1.1 Economic indicators, 1960-75 4

1.2 Trends in public and social expenditure as a percentage of GDP, 1960-75

1.3 Economic indicators, 1975-93

1.4 Percentage changes in annual rates of productivity, 1960-92

1.5 Trends in public and social expenditure as a percentage of GDP, 1980-93

1.6 Percentage of population aged 65 or over, 1960-2040 11

1.7 Percentage of lone parents, 1980 and 1990

1.8 Annual employment/population ratios, 1980-90/91 13

1.9 Direct taxes, indirect taxes and social security contributions as a percentage of GNP, 1981 and 1991

1.10 Net public debt and debt interest payments as a percentage of GDP, 1979, 1990 and 1993

5.1 Trends in public spending, 1978-79 and 1992-93 108

5.2 Income changes between 1979 and $1991 \quad 112$

7.1 Division of social security benefits by function, $1991 \quad 146$

9.1 Working-age population per elderly and per dependent person, 1960-2020

9.2 Employment indicators in EC countries, $1992 \quad 185$

9.3 Family trends in Europe, 1960-92 188

9.4 Households in poverty, 1980, 1985 and 1988

9.5 Trends in income distribution: Gini coefficients 196

10.1 State spending, investment and economic success, 1984-94

10.2 Expectations and legitimacy, Eurobarometer $1992 \quad 208$

10.3 Dissatisafaction with social protection, Eurobarometer 1992 


\section{List of Contributors}

Elisabet Almeda is a Researcher in Gender issues in the Department of Public Administration, Pompeu Fabra University, Barcelona, Spain.

Vic George is Professor of Social Policy and Social Work, University of Kent, Canterbury, UK.

Arthur Gould is a Senior Lecturer in Social Policy, University of Loughborough, UK.

Linda Hantrais is Professor of Modern Languages and Director of the European Research Centre, University of Loughborough, UK.

Roger Lawson is a Senior Lecturer and Head of the Department of Social Policy and Sociology, University of Southampton, UK.

Mauro Niero is Professor of Social Welfare, University of Venice, Italy.

Sebastia Sarasa is Professor of Public Policy, Pompeu Fabra University, Barcelona, Spain.

Peter Stathopoulos is Professor of Social Planning and Social Policy, Technological Educational Institute, Athens, Greece.

Peter Taylor-Gooby is Professor of Social Policy, University of Kent, Canterbury, UK. 


\section{Introduction}

Several recent reports by the European Community and the OECD view social and economic policy as inseparable. They consider active social policies as not only conducive to economic growth but as necessary prerequisites to it. On the other hand, they stress that low or zero rates of economic growth inevitably make the achievement of social policy goals very difficult, if not impossible. It is the balance and the right mix of social and economic policies that is the crux of the matter for a vigorous welfare state.

In this volume, we consider the social policies of seven European countries during the past fifteen years within their broader economic, political and social environment. They are all now members of the European Union, but with rather different government approaches to economic and social policy. They range from Sweden with its reputation as the prototype of a fully developed welfare state to Greece with a welfare state in the making. The seven countries are also divided between the more affluent countries of Northern Europe - Sweden, Germany, France and the UK where family patterns are unstable and the less affluent countries of the Mediterranean rim - Italy, Spain and Greece - where families tend to be more cohesive. The family and the community play a greater part in welfare provision in the latter than in the former group of countries.

The concern of the book is to examine the social policy experiences of these countries; to understand the demographic, social and economic pressures for increased welfare spending; and to reach some tentative conclusions on the possible future developments in welfare provision. The book shares the view of many writers that the 1980s and 1990s are a rather special period in the development of the welfare state. A number of factors coalesce to produce a political environment that, on one hand, makes for the containment or the reduction of state welfare spending and, on the other, for the expansion of voluntary and private effort. Apart from issues concerning the volume of state welfare, this period has also seen the beginnings of a trend away from unquestioned decision-making structures and towards greater public accountability in welfare services. Thus the 1980s and the 1990s may well mark the beginning of a new era in the history of the welfare state.

The book begins with a review of trends in the economy, labour market, the family, demography, taxation and welfare spending during the post- 
war period in our seven countries (Chapter 1). It then reviews the experience of the seven countries during the years 1980-95 and casts a glance at their likely development in the remaining years of this century (Chapters 2-8). Chapter 9 examines the pressures affecting the demand for welfare today and in the immediate future. While demographic, family and social factors play their part, it is unemployment which directly and indirectly is the major pressure point. Chapter 10 looks at the political responses of the seven countries.

There is a limited tendency towards convergence in spending levels (as lower spending Mediterranean countries with left-wing governments increase provision and Northern governments retrench) and in the broad structure of provision (as Bismarckian social insurance systems are subsidised from direct taxation and are extended to include at least some groups among the 'new poor' who are not strictly entitled on the basis of work records). So far so good for the protagonists of Maastricht! How far this trend will go in eroding the disparity between welfare systems based essentially on social insurance and those which place much greater reliance on direct state tax is unclear. Nowhere are welfare reforms adequate to meet the needs of those who have been penalised as a result of the current changes in family life and patterns of employment. So far political ideology has had a real but limited effect on welfare reform in recessionary times, although the evidence of Chapter 1 indicates that the test for the stability of welfare systems has not yet arrived. The exception is the UK, where a right-wing government has achieved substantial welfare cuts.

We are immensely grateful to all our contributors without whose work the book would not have been possible. We are also grateful to Jan Terpstra of the University of Nijmegen, the Netherlands; to Ramesh Mishra of the University of York, Canada; and to Paul Wilding of the University of Manchester, UK, for valuable comments on several chapters. As editors, we are jointly responsible for any errors and any weaknesses of the book.

Social policy debates will assume increasing importance within the European Union because of the increasing pressures for welfare expansion, the uncertainties surrounding the future of economic growth and the new ideas of how welfare should be provided and administered. The need for comparative studies of European social policies is greater than ever before and we hope this volume will make some contribution in the understanding of the forces that affect the development of policy in different countries. 